\title{
STRATEGI PENERAPAN SISTEM INFORMASI E-FILING SEBAGAI BENTUK KEBIJAKAN PUBLIK DALAM MENINGKATKAN KEPATUHAN WAJIB PAJAK DI INDONESIA
}

\author{
Purwono $^{1) *}$, Manapar Banjar Nahor ${ }^{2)}$, Rizky Fajri ${ }^{3)}$, Sukur Purwanto ${ }^{4)}$, Ismail Fahmi ${ }^{5)}$, Asep Saefudin ${ }^{6)}$ \\ ${ }^{1}$ KPP Pratama Soreang, Direktorat Jenderal Pajak \\ Bandung, Jawa Barat, Indonesia \\ poervika@gmail.com
}

${ }^{2}$ KPP Pratama Bandung Tegallega, Direktorat Jenderal Pajak

Bandung, Jawa Barat, Indonesia

martin.6abe@gmail.com

${ }^{3}$ KPP Madya Bandung, Direktorat Jenderal Pajak

Bandung, Jawa Barat, Indonesia

kiki_fajri@gmail.com

\author{
${ }^{4}$ Kanwil DJP Jawa Barat I, Direktorat Jenderal Pajak \\ Bandung, Jawa Barat, Indonesia \\ masskur@gmail.com \\ ${ }^{5}$ Kanwil DJP Jawa Barat I, Direktorat Jenderal Pajak \\ Bandung, Jawa Barat, Indonesia \\ ismail.isfa@gmail.com \\ ${ }^{6}$ Kanwil DJP Jawa Barat I, Direktorat Jenderal Pajak \\ Bandung, Jawa Barat, Indonesia \\ Asep.ponti@gmail.com
}

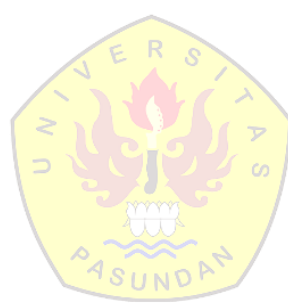

\begin{abstract}
ABSTRAK
Perpajakan telah menjadi sumber utama penerimaan negara untuk melaksanakan Pembangunan Nasional sebagai berkelanjutan dan kegiatan berkelanjutan, dengan tujuan meningkatkan kesejahteraan masyarakat baik secara materi maupun spiritual. Tujuan penelitian ini mengungkapkan Strategi Implementasi Sistem Informasi e-filing dalam mengoptimalkan Kepatuhan Wajib Pajak. Metode penelitian menggunakan model yang diperoleh dari fenomena di lapangan yang dibentuk berdasarkan teori parsial antar model, sehingga dari beberapa teori pendukung diperoleh model. Pendekatan yang digunakan adalah fenomenologi hermeneutis. Subjek penelitian wajib pajak dan pajak, objek strategi penelitian untuk menerapkan sistem informasi e-filing dan kepatuhan wajib pajak. Penelitian ini dilakukan di Kantor Direktorat Jenderal Pajak di Jawa Barat dari Jakarta 2016-2018. Hasil penelitian ini memberikan kesimpulan: Strategi untuk menerapkan sistem informasi e-filing miliki sudah cukup baik dan mendukung dan masih relevan dengan hasil penelitian sebelumnya. Namun, strategi untuk menerapkan sistem informasi e-filing belum dapat meningkatkan kepatuhan wajib pajak perusahaan dan swasta secara penuh; Ketentuan kepatuhan Wajib Pajak dalam memenuhi kewajibannya dianggap rendah; strategi penerapan sistem informasi e-filing berperan dalam mengoptimalkan kepatuhan wajib pajak, di satu sisi kepatuhan wajib pajak menurun, tetapi bukan sebagai hasil dari sistem informasi e-filing yang tidak berhasil, kepatuhan wajib pajak berperan dalam memaksimalkan pendapatan pajak negara.
\end{abstract}

Kata kunci: Strategi Implementasi, system e-filing, kepatuhan wajib pajak. 


\section{ABSTRACT}

Taxation has become the main source of state revenue for implementing National Development as a sustainable and sustainable activity, with the aim of improving the welfare of the community both materially and spiritually. The purpose of this research is to reveal the e-filing Information System Implementation Strategy in optimizing Taxpayer Compliance. The research method uses a model obtained from phenomena in the field which is formed based on a partial theory between models, so that from several supporting theories a model is obtained. The approach used is hermeneutical phenomenology. The subject of research on tax and taxpayers is the object of research strategies for implementing an e-filing information system and taxpayer compliance. This research was conducted at the Office of the Directorate General of Taxes in West Java from Jakarta 2016-2018. The results of this study provide conclusions: The strategy for implementing an e-filing information system is quite good and supportive and is still relevant to the results of previous research. However, the strategy to implement an e-filing information system has not been able to fully improve corporate and private taxpayer compliance; Taxpayer compliance provisions in fulfilling their obligations are considered low; The strategy of implementing the e-filing information system plays a role in optimizing taxpayer compliance, on the one hand taxpayer compliance has decreased, but not as a result of an unsuccessful efiling information system, taxpayer compliance plays a role in maximizing state tax revenue.

Keywords: Implementation Strategy, e-filing system, taxpayer compliance.

\section{PENDAHULUAN}

Ketahanan fiskal merupakan kunci dalam program exit strategy pemerintah guna meningkatkan pembangunan berkelanjutan. Pilihan pajak sebagai sumber pendapatan negara antara lain, karena sektor ini cenderung melebihi jumlah dari apa yang dapat diperoleh dari sekedar mencetak uang, membebani harga terhadap konsumen secara langsung, atau dengan cara berhutang (James dan Alley, 2010), dengan demikian pajak dengan sistemnya menjadi pilihan sumber utama dalam upaya meningkatkan penerimaan pemerintah. Wajib Pajak sebagai bagian dari pelaku ekonomi makro memiliki peranan penting termasuk dalam mekanisme perpajakan. Kepatuhan wajib pajak dalam memenuhi kewajiban pajaknya merupakan hal yang terkait dengan sistem perekonomian makro secara keseluruhan. Keinginan untuk memenuhi aturan adalah di samping faktor masalah eksistensi pribadi seseorang juga pengaruh faktor lingkungan luar seseorang. Seseorang yang berakhlak moral baik mempunyai etika baik, cenderung mematuhi aturan. Demikian pula nilai-nilai orientasi seseorang bahkan pilihan resiko sekalipun akan menentukan langkah seseorang. Di pihak lain faktor situasional turut ambil peranan dalam membentuk pola perilaku seseorang dalam menentukan langkahnya. Aspek situasional bisa menyangkut sanksi audit, keadilan dan kepastian hukum (Trivedi, et al., 2003).

Sehubungan dengan pajak sebagai kewajiban warga negara, maka kepatuhan ini merupakan salah satu unsur voluntary contribution dari warga negara. Buckley, et., al., (2000) telah penelitian dan mengemukakan bahwa voluntary contribution tersebut dipengaruhi oleh orientasi nilai dan pendapatan. Feld dan Frey (2003) mengemukakan tentang tax compliance yang dianalisis berdasarkan keputusan individu yang memilih antara membayar atau menghindari pajak. Menurut hasil penelitian ini diketahui bahwa hubungan antara dua pihak antara fiskus dan wajib pajak dan dalam kaitan ini terdapat semacam kontrak psikologis. Studi di Swiss menunjukkan bahwa partisipasi politis yang lebih kuat, hal yang lebih penting dari sekedar kontrak tersebut adalah masalah moral itu sendiri. Jika dihubungkan dengan daerah, maka kapasitas pajak (tax capacity) daerah sangat dipengaruhi oleh tingkat kemajuan daerah yang tercermin pada Produk Domestik Regional Bruto (PDRB) yang meningkat dengan kata lain, terdapat hubungan yang kuat antara pajak daerah dengan PDRB sebagai pencerminan potensi perpajakan di daerah. Meningkatkan kepatuhan wajib pajak (tax compliance) khususnya kepatuhan yang bersifat sukarela (voluntary) merupakan salah satu sasaran utama yang ingin dicapai oleh Direktorat Jenderal Pajak (DJP). Kepatuhan 
yang meningkat pada akhirnya akan berpengaruh secara positif terhadap penerimaan pajak. Namun demikian, kondisi kepatuhan di Indonesia saat ini, belum sesuai harapan, terutama jika menggunakan angka penyampaian Surat Pemberitahuan (SPT) Tahunan sebagai indikator.

Tabel 1. Rasio Kepatuhan Penyampaian SPT PPh Tahunan di Indonesia

\begin{tabular}{|l|r|r|r|r|}
\hline \multirow{2}{*}{\multicolumn{1}{c|}{ URAIAN/TAHUN }} & \multicolumn{3}{c|}{ TAHUN } \\
\cline { 2 - 5 } & $\mathbf{2 0 1 3}$ & $\mathbf{2 0 1 4}$ & $\mathbf{2 0 1 5}$ & \multicolumn{2}{c|}{$\mathbf{2 0 1 6}$} \\
\hline Wajib Pajak (WP) Terdaftar & 24.347 .763 & $\begin{array}{c}27.379 .2 \\
56\end{array}$ & 30.044 .103 & 32.769 .215 \\
\hline WP Terdaftar Wajib SPT & 17.731 .736 & 18.357. & 18.159 .840 & 20.165 .718 \\
\hline Target Rasio Kepatuhan (\%) & $65,00 \%$ & $70,00 \%$ & $70,00 \%$ & $72,50 \%$ \\
\hline Target Rasio Kepatuhan- SPT (3X2) & 11.525 .628 & 12.852. & 12.711 .888 & 14.620 .146 \\
\hline Realisasi SPT & 9.966 .833 & 10.852. & 10.972 .336 & 12.735 .463 \\
\hline Rasio Kepatuhan (5:2) & $56,21 \%$ & $59,12 \%$ & $60,42 \%$ & $63,15 \%$ \\
\hline Capaian Rasio Kepatuhan (5:4) & $86,48 \%$ & $84,45 \%$ & $86,32 \%$ & $87,10 \%$ \\
\hline
\end{tabular}

Sumber: Laporan Keuangan DJP 2013-2016.

Upaya DJP untuk meningkakan kepatuhan telah dan senantiasa terus dilakukan dengan mengacu kepada empat pilar perpajakan Indonesia yaitu: (1) Penyuluhan, (2) Pelayanan, (3) Pemeriksaan (termasuk penyidikan), dan (4) Penagihan. Kebijakan yāng sedang diambil adalah mencanångkan tahun 2015 sebagai Tahun Pembinaan Wajib Pajak (TPWP). Sementara itu, wacana penerapan kebijakan pengampunan pajak (tax amnesty) masih terus dikaji dan dibahas secara intensif termasuk dengan pihak legislative (2016). Mengantisipasi perkembangan informasi dan teknologi, DJP berusaha untuk memenuhi aspirasi Wajib Pajak (WP) dengan mempermudah tata cara pelaporan Surat Pemberitahuan (SPT) baik itu SPT Masa maupun SPT Tahunan. Pembaharuan dalam sistem perpajakan yang dilakukan oleh DJP tersebut tidak lain adalah sebagai bagian dari reformasi perpajakan, khususnya administrasi perpajakan. Program reformasi administrasi perpajakan diwujudkan dalam penerapan system administrasi perpajakan modern yang memiliki ciri khusus, antara lain struktur organisasi yang dirancang berdasarkan fungsi, tidak lagi menurut seksi-seksi berdasarkan jenis pajak, perbaikan pelayanan bagi setiap wajib pajak melalui pembentukan account representative dan compliant center untuk menampung keberatan Wajib Pajak.

Sistem administrasi perpaj akan modern juga mengikuti kemajuan teknol ogi dengan pelayanan yang berbasis e-system seperti e- SPT, e-filing, e-Paym ent, dan e-Registration yang diharapkan meni ngkatkan mekanisme kontrol yang lebih efektif yang ditunjang dengan penerapan Kode Etik Pegawai Direktorat Jenderal Pajak yang mengatur perilaku pegawai dalam melaksanakan tugas dan pelaksanaan good governance. Permasalahan yang terjadi pada pelayanan terhadap Wajib Pajak berupa system informasi $e$-filing, yaitu masih terdapat kekurangan terlihat dari situs tersebut nampaknya sulit di akses lantaran penuhnya WP yang ingin membayar pajak, yang mengakibatkan ketidaknyamanan wajib pajak dalam menggunakan dan memanfaatkan pelayanan berupa e-filing dalam pelaporan SPT tahunan. Destination Statement Direktorat Jenderal Pajak Tahun 2015-2019. 
Kebijakan: Jurnal Ilmu Administrasi

Volume 12, Nomor 1, Januari 2021

E-ISSN: 2656-2820

P-ISSN 1829-5762

Tabel 2. Destination Statement DJP Tahun 2015-2019

\begin{tabular}{|l|r|r|r|r|c|}
\hline \multicolumn{1}{|c|}{ INDIKATOR } & \multicolumn{5}{c|}{ TAHUN } \\
\hline $\begin{array}{l}\text { Tax Ratio (\%) } \\
\begin{array}{l}\text { Penerimaan Pajak } \\
\text { (Rp Trilliun) }\end{array} \\
\text { SPT melalui } \text { e-Filing (Rp Juta) }\end{array}$ & $\mathbf{2 0 1 5}$ & $\mathbf{2 0 1 6}$ & $\mathbf{2 0 1 7} * \mathbf{2 0 1 8}$ & $\mathbf{2 0 1 6}$ \\
\cline { 2 - 6 } & 1.294 & 1.512 & 1.737 & 2.007 & 2.329 \\
\hline Jumlah WP terdaftar (Juta) & 2 & 7 & 14 & 18 & 24 \\
\hline
\end{tabular}

Sumber: LKDJP (2016), Ket:*estimasi.

Selain itu Menteri Keuangan RI (Mulyani, 2017) menyatakan bahwa sayangnya kepatuhan dari Wajib pajak di Indonesia masih memprihatinkan. Jumlah rasio kepatuhan yaitu: yang membayar dan menyerahkan SPT dbandingkan dengan wajib pajak yang terdaftar hanya 56\% pada tahun 2013 dan sedikit mebgalami peningkatan pada tahun 2016, yaitu 62,2\%. 20 juta Wajib Pajak yang menyrahkan SPTnya hanya 12,56 Juta saja. Dengan kata lain yang Kepatuhan Wajib Pajak ini termasuk kategori rendah jika dibandingkan dengan Negara-negara di Kawasan Asia maupun Dunia. Banyak faktor yang mempengaruhi kepatuhan wajib pajak di antaranya dikemukakan oleh Supriyadi (2016), bahwa penerapan

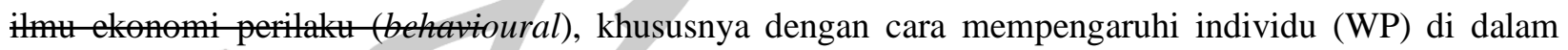
pengambilan keputusan. Penerapan ilmu ekonomi perilaku telah mengalami perkembangan yang cukup pesat tidak hanya di negara-negara maju (seperti Amerika Serikat, Inggris, Canada dan Australia) tetapi juga di beberapa negara lainnya (seperti Argentina, Peru, Mexico, dan Chile).

Hasil penelitian yang dilakukan di Indonensia, terkait dengan penerapan system informasi $e$-filing pernah dilakukan Wahyuningsih, Winaya, dan Yasintha (2018), berkesimpulan e-filing system merupakan realisasi program pemerintah untuk membantu pembayar pajak individu atau pembayar pajak perusahaan untuk menjalankan kewajibannya. Sistem e-filing telah diimplementasikan dan wajib untuk semua wajib pajak di Indonesia sejak 2014. Selama 2 (dua) tahun terakhir implementasi, penggunaan sistem e-filing dalam mengirimkan SPT tahunan seperti telah berjalan cukup baik, tetapi jika dilihat dari jumlah notifikasi tahunan yang masuk melalui $e$ - filing system, angka tersebut masih belum dapat meningkatkan kepatuhan dari wajib pajak orang pribadi terhadap maksimumnya penerimaan negara. Sistem e-filing hanya dapat digunakan oleh pembayar pajak individu yang tahu internet dan wajib pajak perorangan yang memiliki bentuk SPT yang sederhana. Temuan penting dalam penelitian tersebut bahwa penerapan system infromasi e-filing sudah baik, tetapi belum mampu meningkatkan kepatuhan wajib pajak individu secara maksimal karena kurangnya sosialisasi dan kesadaran wajib pajak individu. Hambatan yang harus diatasi adalah sosialisasi tidak merata, para pembayar pajak tidak tahu internet dan antrean panjang saat mencari e-pin.

Selanjutnya hasil penelitian Rustiyaninsih (2011), berkesimpulan bahwa kepatuhan wajib pajak dipengaruhi oleh (a) pemahaman WP terhadap system self assessment, dengan memahami system pemungutan pajak (1) Official assessment system, system pemungutan pajak yang besarnya ditetntukan oleh fiskus; 2. Self Assessment system, system pemungutan pajak yang besarnya ditemntukan oleh WP; dan Witholding system, system pemungutan pajak yang besarnya ditentukan oleh pihak ketiga); (b) kualitas pelayanan, yang meliputi: mutu dan produkstivitas pelaksanaan petugas, upaya mengefektifkan system dan tata laksana pelayanan, tumbuhnya kreativitas, prakarsa, dan peran serta masyarakat. Berdasarkan hasil penelitian tersebut, beberapa perbedaan dan keterbatasan antara penelitian yang satu dengan penelitian 
lainnya, di antaranya: (1) belum ditemukan satu definisi yang sama mengenai kepatuhan wajib pajak; (2) Kepatuhan wajib pajak dibangun dari konstruk yang berbeda; (3) Belum memasukkan system informasi $e$ filing sebagai konstruk dalam membangun kepatuhan wajib pajak, dan (4) Belum memasukkan system informasi $e$-filing sebagai variabel yang berpengaruh terhadap kepatuhan Wajib Pajak. Dilihat dari unsur yang dikaji dan metode penelitian yang digunakan penelitan sebelumnya bereda dengan penelitian ini. Pendekatan yang digunakan penelitian sebelum pada umumnya menggunakan metode dengan pendekatan kuantitaif, sedangkan penelitian ini akan dilakukan dengan pendekatan kualitatif, dengan demikian, kepatuhan wajib pajak dan segala karateristiknya menarik untuk dikaji lebih jauh, karena akan bermanfaat bukan saja bagi pengembangan ilmu pengetahuan khususnya perilaku akuntansi (Accounting Behavior) dan Akuntansi Perpajakan (Tax Accounting), tetapi juga akan bermanfaat bagi pengambil kebijakan dan otoritas pajak dalam meningkatkan kepatuhan wajib pajak dengan mempelajari dan mengimplementasikan system informasi e-filing.

\section{METODE}

Dasar pemikiran (logical-construct), penelitian ini menggunakan paradigma penelitian Analisis Kebijakan Publik dalam menerapkan manajemen strategi yang harus dilakukan oleh top manajemen dalam upaya meningkatkan dan menciptakan kreativitas nilai (Value Creation), Inovasi secara interpreneurship guna mengembangkan aktivitas organisasi. Teori yang mendasari penelitian ini, yaitu: Teori Organisasi sebagai Grand Theory dan Teori Perilaku Organisasi sebagai Middle Range Theory. Manajemen, Manajemen strategik, Manajemen sistem informasi, dan sistem perpajakan sebagai Applied Theory. Grand theory dimaknai sebagai teori umum yang mendasari setiap teori yang diturunkân, guna menjelaskan keseluruhan konsep yang menjadi fokus penelitian. Istilah Grand theory pertama kali diungkapkan oleh C. Wright Mills (Rusdin, 2015). Lebih jauh dijelaskan Rusdin (2015) bahwa Grand theory berkenaan dengan bentuk abstrak tertinggi suatu peneorian yang tersusun atas konsep yang menjadi fokus kajian dalam suatu penelitian. Teori Umum (Grand Theory) menekankan pada teori dasar yang diturunkan menjadi teori penghubung (Middle Range Theory) dengan Teori Terapan (Applied Theory) yang mengerucut pada penjabaran konsep-konsep lebih mendalam.

Penelitian dilakukan dengan pendekatan kualitatif yang merujuk pada pandangan Denzin dan Lincolin (2009), Creswell (2013a; 2013b), dan Sekaran (2016) bahwa metode penelitian dengan pendekatan kualitatif, merupakan bidang antar-disiplin, lintas-disiplin, dan kadang-kadang kontra-displin, penelitian berusaha untuk mengungkapkan gejala secara holistik-konstektual melalui pengumpulan data dari latar alami dengan memanfaatkan diri peneliti sebagai instrument kunci. Metode Analisis Data dilakukan dengan model strategi kombinasi (embedded strategy model), yaitu (Creswell, (2013a; 2013b): metode penelitian yang mengkombinasikan data primer dengan data sekunder secara simultan (secara bersama-sama) tetapi bobot metodenya berbeda, yaitu metode analisis data primer digunakan untuk mengumpulkan dan menganalisis data utama, sedangkan analisis data sekunder digunakan untuk memperoleh data guna melengkapi data yang diperoleh dari metode analisis data primer. Pada penelitian ini peneliti menggunakan metode primernya dengan penelitian kualitatif dan metode primernya dilengkapi dengan metode sekunder dengan penelitian kuantitatif.

Desain penelitian yang digunakan adalah desain penelitian studi kasus tunggal (single case study design). Melalui studi kasus, dapat dilakukan kajian yang mendalam mengenai perilaku suatu unit individu (perorangan, keluarga, kelompok, atau pranata sosial suatu masyarakat). Dalam penelitian ini satu unit yang diteliti adalah sebuah keluarga multikultural yang menerapkan pola asuh otoritatif. Creswell (2013a; 2013b), mengungkapkan bahwa "Single-case studies are also ideal for revelatory cases where an observer may have 
access to a phenomenon that was previously inaccessible”. Studi kasus tunggal sangat ideal untuk kasuskasus yang tersembunyi. Pada kasus tersebut pengamat dapat memasuki fenomena yang sebelumnya tidak dapat diakses. Desain studi kasus tunggal digunakan untuk memperoleh makna dari gambaran umum tentang kasus perpajakan di Indonesia. Desain studi kasus bertujuan untuk menggali (explore) dan mendeskripsikan (describe) secara rinci tentang fenomena yang diteliti. Jenis studi kasus tunggal dalam penelitian ini adalah studi kasus observasi (Bogdan dan Biklen, 2001). Dalam studi kasus tunggal observasi penekanannya adalah pada penggunaan observasi untuk menjaring informasi-informasi empiris yang empiris dan aktual dari unit analisis penelitian, baik yang menyangkut kehidupan individu maupun unitunit sosial tertentu dalam masyarakat.

\section{PEMBAHASAN}

Teknis analisis yang digunakan dalam penelitian ini, yaitu: berdasarkan paradigma penelitian melalui teori, konsep secara ontology, epistemology sehingga di peroleh tujuan secara axiologi. Teknik analisis berdasarkan data yang telah diperoleh secara metode Triangulasi baik hasil wawancara, focus disscution group (FDG) maupun hasil studi dokumentasi pada Direktorat Jenderal Pajak Wilayah Jawa Barat.

\section{Peranan Sistem Infromasi $e$-filling dalam mengoptimalisasikan kepatuhan Wajib Pajak di Jawa Barat}

Tingkat kepatuhan wajib pajak di Jawa Barat masih rendah dan cenderung menunjukkan tren menurun dalam beberapa tahu terakhir. Hal ini menunjukkan kesadaran melakukan kewajiban perpajakan di Jawa Barat masih rendah. Masalah kepatuhan pajak ini merupakan masalah DJP yang serius. Rendahnya kepatuhan ini pada akhirnya akan berpengaruh pada realisasi penerimaan pajak. Hal ini disebabkan tidak tercapainya penerimaan pajak sejak tahun 2016-2107 dipengaruhi juga oleh rendahnya tingkat kepatuhan WP dalam melaporkan SPT melalui e-filling. Secara umum, e-filing melalui situs Direktorat Jenderal Pajak (DJP) di alamat www.pajak.go.id adalah sistem pelaporan SPT menggunakan sarana internet tanpa melalui pihak lain dan tanpa biaya apapun, yang dibuat oleh DJP untuk memberikan kemudahan bagi WP dalam pembuatan dan penyerahan laporan SPT kepada DJP sehingga menjadi lebih cepat, dan lebih murah. Sistem e-filling dapat dijelaskanbahwa sistem e-filling adalah suatu cara penyampaian Surat Pemberitahuan yang dilakukan melalui sistem on-line dan realtime hal tersebut dinyatakan oleh Fidel (2010:56). E-filling memiliki beberapa syarat dan ketentuan yang harus dilalui, yakni Wajib Pajak harus memiliki Electronic Filling Identification Number (e-FIN).

Sistem e-filling memiliki tujuh manfaat yang dapat dirasakan secara langsung bagi Wajib Pajak dalam melakukan pelaporan Surat Pemberitahuannya. Manfaat tersebut adalah sebagai berikut: (1) Wajib pajak dapat melaporkan SPT dengan aman, cepat serta kapan saja karena bisa dilaporkan selama 24 jam setiap hari; (2) Dalam melaporkan surat pemberitahuan tahunan wajib pajak tidak dikenakan biaya sama sekali; (3) Sistem ini menggunakan system komputer sehingga perhitungan dapat dilakukan secara tepat; (4) Pengisian SPT berbentuk wizard sehingga wajib pajak bisa lebih mudah dalam menyampaikan SPTnya; (5) Terdapat sistem validasi dalam menyampaikan SPT, sehingga wajib pajak tidak akan pernah kurang atau tidak lengkap dalam menyampaikan SPTnya; (6) Karena menggunakan sistem online atau elektronik, jadi dalam menyampaikan SPTnya wajib pajak tidak menggunakan kertas lagi sehingga bisa menghemat biaya kertas serta ramah lingkungan; dan (7) Dokumen pelengkap lain tidak perlu lagi dibawa ke Kantor Pelayanan Pajak dimana wajib pajak tersebut terdaftar. Dengan e-filing, WP tidak perlu lagi menunggu antrian panjang di lokasi drop box maupun Kantor Pelayanan Pajak (KPP). 
Hal ini merupakan salah satu terobosan baru pelaporan SPT yang digulirkan DJP untuk membuat WP semakin mudah dan nyaman dalam melaksanakan kewajiban perpajakannya. Untuk saat ini, e-filling melayani penyampaian dua jenis SPT, yaitu: (1) SPT Tahunan PPh WP Orang Pribadi Formulir 1770S. Digunakan bagi WP Orang Pribadi yang sumber penghasilannya diperoleh dari satu atau lebih pemberi kerja dan memiliki penghasilan lainnya, yang bukan dari kegiatan usaha dan/atau pekerjaan bebas. Contohnya karyawan, Pegawai Negeri Sipil (PNS), Tentara Nasional Indonesia (TNI), Kepolisian Republik Indonesia (POLRI), serta Pejabat Negara lainnya, yang memiliki penghasilan lainnya antara lain sewa rumah, honor pembicara/pengajar/pelatih dan sebagainya; (2) SPT Tahunan PPh WP Orang Pribadi Formulir 1770SS, digunakan bagi orang pribadi yang sumber penghasilannya dari satu pemberi kerja (sebagai karyawan) dan jumlah penghasilan brutonya tidak melebihi Rp60.000.000 (enam puluh juta rupiah) / tahun serta tidak terdapat penghasilan lainnya kecuali penghasilan dari bunga bank dan bunga koperasi.

Tahap ke tiga siklus hak dan kewajiban Wajib Pajak (WP) tentang pelaporan pajak, telah disinggung sekilas tentang adanya fasilitas penyampaian Surat Pemberitahuan (SPT) Tahunan Pajak Penghasilan (PPh) WP Orang Pribadi secara online melalui aplikasi e-filing. Guna menguji kepatuhan WP dalam melakukan pemenuhan kewajiban perpajakannya. Kepatuhan merupakan perilaku WP dalam melaksanakan kewajiban perpajakannya sesuai dengan peraturan yang berlaku (Witono, 2008). Dengan kebijakan implementasi $e$ filling system yang tepat, diharapkan kepatuhan WP akan meningkat dan pada akhirnya akan bermuara pada tercapainya penerimaan pajak. Penerapan system informasi e-filing pada DJP Kanwil Jawa Barat merupakan indikator pengukuran manajemen Strategis Pelayanan Prima, yaitu penyampaian SPT melalui $e$-filling. SPT yang disampaikan melalui e-Filing adalah SPT Tahunan PPh Formulir 1770, 1770S, dan 1771 yang disampaikan melalui e-filing atau e-SPT pada tahun berjalan. Target dari IKU ini adalah WP sasaran e-filing. WP sasaran e-filing adalah WP yang diproyeksikan akan menyampaikan SPT Tahunan PPh Formulir 1770, 1770S, dan 1771, yang jumlahnya ditentukan oleh Kantor Pusat.

Kepatuhan formal yang dimaksud adalah pemenuhan penyampaian Surat Pemberitahuan (SPT) Tahunan PPh Wajib Pajak (WP) Badan dan WP Orang Pribadi (OP) Non Karyawan. Kinerja yang diukur adalah rasio kepatuhan penyampaian SPT Tahunan dengan membandingkan antara jumlah penyampaian SPT Tahunan PPh Badan Dan OP Non Karyawan (tidak termasuk pembetulan SPT Tahunan PPh) dengan jumlah WP Badan dan OP Non Karyawan terdaftar yang wajib menyampaikan SPT Tahunan PPh. Hasil penelitian ini masih relevan dengan hasil penelitian Slemrod dan Gillitzer (2013) bahwa untuk mengukur keberhasilan penerimaan pajak dalam suatu negara (daerah) dapat menggunakan indikator-indikator: rasio pajak (tax ratio), kapasitas pajak (tax capacity) dan upaya perpajakan (tax effort). Selanjutnya penjelasan mengenai karakteristik/indikator tersebut dijelaskan oleh Bird dan Prest (Slemrod dan Gillitzer, 2013), bahwa kapasitas pajak (tax capacity) adalah ukuran rasio pajak terhadap pendapatan nasional (PDB) atau pendapatan regional (PDRB) yang digunakan untuk mengukur kapasitas pajak dalam suatu negara atau daerah jika terjadi peningkatan dalam penerimaan pajak. Sedangkan upaya perpajakan (tax effort) adalah indeks yang diperoleh dengan membagi rasio pajak aktual terhadap pendapatan nasional dengan rasio pajak yang diestimasi. Dua indikator perpajakan tersebut yakni tax effort dan tax capacity mempunyai suatu keterkaitan satu dengan lainnya yang dapat menghasilkan suatu implikasi gambaran kategori tingkatan indikator yakni: pemenuhan pelayanan publik, kepatuhan wajib pajak, pelayanan dengan fasilitas e-filling, dan berbagai indikator lainnya.

Selanjutnya penelitian ini juga mendukung hasil penelitian Abdul (2009) yang menyoroti beberapa implikasi potensial dari temuan bagi para pembuat kebijakan untuk mencapai sistem $e$-filing yang berhasil di sebuah negara. Sebagaimana tercermin dalam temuan, sangat penting untuk semua staff lembaga 
mengimplementasikan kebijakan e-government, membekali diri dengan alat-alat ICT yang lebih canggih untuk mengarahkan pengguna. Faktanya adalah bahwa kesenjangan dalam infrastruktur TI dapat mempengaruhi retensi orang untuk terus menggunakan sistem yang disediakan oleh pemerintah. Demikian demikian, penelitian ini mendukung dan masih relevan dengan hasil penelitian sebelumnya, sehingga dapat dijadikan altenatif bagi pembuat kebijakan dalam mengoptimalisasikan penerimaan Negara pada sektor pajak dengan mempelajari strategi penerapan system informasi e-filling dalam mengoptimalkan kepatuhan Wajib Pajak dalam memenuhi kewajibannya.

\section{Hasil Wawancara dengan Pakar Ahli (Expert Ajudgment)}

Berdasarkan hasil wawancara terbatas yang dilakukan, diperoleh informasi bahwa arah dan tujuan kebijakan pemeriksaan yang dilakukan oleh DJP adalah untuk efektivitas pemeriksaan, meningkatkan kepatuhan WP, dan mencapai penerimaan pajak. Kebijakan pemeriksaan merupakan salah satu instrumen untuk mendukung upaya pencapaian penerimaan pajak yang telah ditetapkan oleh pemerintah. Tingkat kepatuhan wajib pajak di Jawa Barat dalam menyampaikan surat pemberitahuan tahunan (SPT) pajak dirasakan masih kurang. Dari target 72 persen, hingga dua hari menjelang penutupan masa penyampaian SPT, hanya 52 persen wajib pajak yang melapor. Hingga penelitian ini dilakukan baru 52 persen wajib pajak yang telah melaporkan SPTnya, berdasarkan wawancara dengan kata Kepala Kantor Wilayah Direktorat Jenderal Pajak Jawa Barat, pihaknya telah melakukan sosialisasi ke setiap perusahaan hingga pengiriman surat kepada wajib pajak. Dalam sosialisasi juga diterangkan ada sanksi bagi wajib pajak yang tidak melaporkan SPT. Sosialisasi terkait SPT dilakukan setiap 2-3 hari sekali ke perusahaan. Tapi tetap saja ada yang tidak mau lapor. Diperkirakan ini ada di angka 30 persen. Pelaporan SPT sudah dipermudah. Wajib pajak bisa menggunakan aplikasi $e$-Filling pajak yang bisa diakses di handphone. Ini memudahkan wajib pajak tanpa perlu mendatangi kantor pajak. Tapi tetap saja tingkat kepatuhan wajib pajak terbilang rumit, hal tersebut menjadi paradigma tersendiri bagi Direktorat Jenderal pajak. Menurutnya lebih mudah menaikkan pertumbuhan orang bayar pajak dibandingkan orang lapor pajak. Selain itu, di masyarakat ada persepsi kalau sudah bayar lalu kenapa masih harus lapor.

Saat ini Direktorat Jenderal Pajak telah memberi kelonggaran, pelaporan SPT yang mustinya berakhir 31 Maret diperpanjang hingga 21 April. Hal ini bisa jadi solusi bagi wajib pajak agar segera memenuhi pelaporan pajaknya, dengan harapan wajib pajak segera menunaikan kewajiban pelaporan. Batas waktu SPT sampai 21 April 2018, namun pembayarannya tidak diundur, tetap batas akhirnya sampai 31 Maret 2018. Selanjutnya hasil wawancara dengan kepala Kanwil DJP Jawa Barat II, menyatakan bahwa tingkat kepatuhan Wajib Pajak di lingkup kerja Kantor Wilayah Direktorat Jenderal Pajak Jawa Barat II dalam hal pelaporan surat pemberitahuan tahunan pajak sangat rendah. Hingga per 31 Desember 2017, DJP Jabar II berada pada peringkat ke-31 dari total 33 Kanwil se-Indonesia perihal kepatuhan wajib pajak. Kepala Seksi Kerja Sama dan Hubungan Masyarakat Kanwil DJP Jabar II menyatakan, bahwa terdapat 1,6 juta Wajib Pajak dari kalangan karyawan, 106 ribu Wajib Pajak Badan, dan 240 ribu Wajib Pajak dari kalangan pengusaha.

Ketiga kelompok tersebut, kepatuhan kalangan pengusaha dari unsur nonkaryawan serta pelaku UKM yang terendah, yakni hanya 32 persen. Sementara kelompok Wajib Pajak Badan juga Karyawan, kepatuhannya berkisar 54 persen dan 55 persen. Sisanya, para pemilik NPWP yang tidak melaporkan SPT dikarenakan berbagai alasan, salah satu kondisi yang banyak terjadi ialah pembuatan NPWP untuk keperluan melamar kerja. Kepemilikan NPWP yang dijadikan prasyarat melamar kerja itu membuat para pencari kerja akhirnya memproses pembuatan NPWP, di salah satu kantor pelayanan, pemohon pembuatan NPWP bahkan bisa mencapai 150 orang per harinya. Permasalahan pun muncul manakala para pelamar 
tersebut nyatanya tidak diterima pada lowongan pekerjaan yang diincar. Walhasil, mereka menjadi pemegang NPWP yang tak memiliki penghasilan tetap hingga akhirnya tak melakukan pelaporan SPT yang semestinya dilakukan setahun sekali. Permasalahan lain yang juga mempengaruhi rendahnya kepatuhan pelaporan SPT, yaitu dari kalangan pelaku usaha yang belum stabil omset usahanya. Saat usaha sedang baik, mungkin mereka tertib dan disiplin. Namun saat usaha lesu, sering kali tak memikirkan hal lain, apalagi semisal pelaporan SPT. Kondisi kedua ini bahkan jamak terjadi pada skala nasional, dari 19 juta pemilik NPWP di Indonesia, sebagian di antaranya merupakan pemilik usaha, dan dari total sekitar 9 juta pemegang NPWP dari kalangan pelaku usaha, hanya satu juta di antaranya yang melaporkan SPT-nya. Sisanya, bisa jadi sama dengan kelompok ketiga, yakni yang tidak melapor karena merasa kesulitan dalam melakukan pengisian. Dalam hal ini, pihaknya akan mengupayakan agar pengisian SPT bisa dipermudah. Salah satu kiat yang diupayakan ialah dengan membuka kelas pajak.

Hasil wawancara lainnya di DJP Kanwil Jabar II, target penerimaan pajak ke Kanwil DJP Jawa Barat II tahun 2017 sebesar Rp 33,7 Triliun, dari target itu hingga awal Januari 2018, penerimaan sudah mencapai angka 85 persen, atau Rp 30,9 Triliun. Penerimaan DJP Kanwil Jabar II merupakan yang terbesar nomor 2 setelah Kanwil Banten. Sedangkan pertumbuhan Wajib Pajak (WP), Kanwil DJP Jawa Barat II, berada di urutan pertama secara nasional. Pertumbuhan WP di Kanwil DJP Jawa Barat II, berada pada angka 8,4 persen. Meskipun tingkat kepatuhan WP di Kanwil DJP Jawa Barat II terhitung rendah, karena berbagai alasan. Namun, yang terbanyak adalah karena faktor minimnya pengetahuan bagaimana cara mengisi dan menyetorkan SPT tahunan. WP terutama yang bergerak di bidang Usaha Mikro Kecil dan Menengah (UMKM), mereka tidak tahu caranya. Namun demikian, DJP Kanwil Jabar II tetap mencari solusi agar mereka mau memenuhi kewajibannya, seperti petugas menghubungi yang Wajib Pajak, untuk memberikan bimbingan bagaimana mengisi dan menyetorkan SPT. Terdapat juga, dengan cara mengundang Wajib Pajak untuk mengikuti kelas pajak. Kepala Seksi Humas KanwilDJP Jawa Barat II, mayoritas warga yang memiliki Nomor Pokok Wajib Pajak (NPWP), adalah karena kebutuhan untuk mengajukan kredit ke bank. Dalam satu hari bisa sampai 150 orang yang mengajukan pembuatan NPWP. Namun pedagang yang pinjam uang di bank, setelah kreditnya turun, mereka tidak lapor SPT. Ini salah satu faktor rendahnya kepatuhan Wajib Pajak. Bagi WP yang bekerja di perusahaan, itu agak mudah. Karena pemotongan pajak, sudah dilakukan ditempatnya bekerja.

Hasil wawancara lainnya, pihak siskus juga mengingatkan, bahwa untuk pembiayaan secara nasional dibutuhkan dana dari Pajak Penghasilan, yang dipungut dari orang dan badan usaha. Kalau ada anggapan, warga sudah bayar Pajak Bumi dan Bangunan (PBB) dan Pajak Kendaraan Bermotor, itu beda bukan pajak penghasilan. PBB dan Pajak Kendaraan Bemotor berguna untuk daerah tempat dia dipungut pajaknya. Tapi kalau untuk pembiayaan secara nasional, seperti untuk gaji TNI-Polri, pembangunan jalan, untuk kesehatan, pendidikan dan gaji PNS, butuh dana dari Pajak Penghasilan. Berdasarkan data, saat ini di seluruh Indonesia dari 250 juta penduduk, hanya 19 juta saja yang sudah memiliki NPWP. 10 juta merupakan karyawan, dan 9 juta merupakan usahawan. Namun, yang sudah melaporkan SPT tahunan dan sudah membayar, baru satu juta.

Hasil wawancara dengan kepala Kantor Wilayah Direktorat Jenderal Pajak Jawa Barat I yang menargetkan pendapatan pajak pada tahun 2017 mencapai Rp 18,1 triliun. Angka itu naik 40\% dibandingkan target tahun sebelumnya yang hanya Rp14 Triliun. Target tahun 2017 Rp18,1 triliun, Kepala Kanwil Dirjend Pajak Jabar I menyatakan bahwa Penyampaian SPT Tahunan di Kantor Pelayanan Pajak Cibeunying, Jalan Purnawarman, Kota Bandung. Menurutnya, tingkat kepatuhan masyarakat membayar pajak masih terbilang rendah. Tahun 2016, dari jumlah wajib pajak sebanyak 1,2 juta orang, tingkat kepatuhannya hanya 55\% namun ditargetkan tahun 2017 bisa mencapai 65\%. Untuk mencapai target 
pendapatan dan peningkatan kepatuhan membayar pajak tersebut pihaknya akan semakin gencar melakukan sosialisasi kepada masyarakat. Masyarakat akan disadarkan pajak merupakan bela negara. Bukan hanya TNI dan Polri saja, masyarakat pun bisa bela negara bisa melalui membayar pajak secara tepat waktu. Selain sosialisasi, pihaknya juga akan mengandalkan sensus wajib pajak dengan target pertumbuhan jumlah wajib pajak sebanyak 250.000 orang/tahun. Namun kegiatan sensus sedikit terhambat dengan keterbatasan jumlah petugas sensus. Jumlah petugas sensus di Indonesia, jelasnya, hanya sekitar 32.000 orang namun jumlah itu kurang sebanding dengan jumlah penduduk Indonesia yang mencapai 260 juta orang. Saat ini pihaknya sedang mengusulkan pertambahan petugas sensus sebanyak 5.000 orang/tahun. Di negara maju seperti Jerman, petugas sensusnya banyak padahal jumlah penduduknya jauh lebih sedikit dibandingkan Indonesia.

Hasil Wawancara dengan kepala DJP Kanwil Jabar II, menunjukkan bahwa kepatuhan untuk membayar pajak di Provinsi Jawa Barat ternyata masih rendah. Data yang ditunjukkan kepala Kantor Wilayah Direktorat Jenderal Pajak I Jawa Barat, baru 2,45 juta warga dari potensi 66 juta warga di wilayah kantor ini yang memiliki nomor induk wajib pajak. Dari 2,45 juta orang yang memiliki Nomor Induk Wajib Pajak (NPWP). Hasil wawancara dengan kepala pemerintahan Jawa Barat (Gubernur Jawa Barat), menyatakan bahwa pemerintah mendorong warga Jabar untuk patuh pada pelaporan pajak. Saat ini, tingkat kepatuhan pajak masyarakat Jawa Barat masih di angka 62\%, berdasarkan data 2017 lalu. Hal ini terungkap saat dirinya melakukan pelaporan Surat Pemberitahuan Tahunan (SPT) PPh orang pribadi melalui sistem pelaporan pajak elektronik atau e-Filing. Pemrov Jabar melaporkan SPT melalui gawai atau alat elektronik tablet. Untuk itu, pada kesempatan ini Pemprov (Gubernur) mengajak kepada semua WP di Jawa Baat agar taat membayar dan melaporkan SPT Pajak, baik untuk perorangan maupun badan. Hasil wawancara lainnya dengan Kepala Pemerintahan Jabar, menyatakan bahwa tata cara pelaporan dan pembayaran pajak saat ini sangat mudah dan murah karena bisa dilakukan melalui $e$-Filing, sehingga bisa dilakukan kapan pun dan dimana pun. Hasil wawancara dengan Kepala Kanwil Jawa Barat I Direktorat Jenderal mengungkapkan, bahwa tingkat kepatuhan masyarakat Jawa Barat terhadap pajak pada 2017 mencapai $62 \%$ atau meningkat dari angka 53,77\% (2016). WP Wajib SPT di Jawa Barat sebanyak 2,6 juta WP, masih dinilai kurang patuh. Mereka (WP) ada yang sengaja menghindar, ada yang tidak tahu, ada juga yang mengecilkan pajak yang harus dibayar. Pada 2017, WP Terdaftar di Jawa Barat sebanyak 6.973.185 WP dan yang Wajib SPT sebanyak 3.093.124 WP. Sementara WP yang melakukan pelaporan sebanyak 1.092.712 WP (62\%), serta WP yang melakukan pembayaran sebanyak 241.287 WP (3\%). Sementara pada 2016, WP Terdaftar di Jawa Barat sebanyak 6.077.349 WP, Wajib SPT sebanyak 3.713.935 WP (59\%), WP Lapor sebanyak 1.996.971 WP (53,77\%), dan WP Bayar sebanyak 223.992 WP (4\%).

Upaya yang dilakukan Kanwil Jawa Barat 1 Direktorat Jenderal Pajak untuk meningkatkan kepatuhan pajak sejauh ini, yaitu sosialisasi kepada WP terutama untuk badan usaha. Kepala DJP Kanwil Jawa Barat I telah melakukan keliling ke Wilayah Jawa Barat I untuk menggugah kesadarannya pengusaha khususnya, namun yang paling banyak adalah orang pribadi. Target yang ditetapkan oleh Kanwil Jabar 1 Direktorat Jenderal Pajak pada 2018 ini untuk pengisian SPT minimal 75\% dari jumlah WP SPT dengan harapkan akan meningkat, karena pajak ini tulang punggung berjalannya Provinsi Jawa Barat ini. Berdasarkan profil APBD Provinsi Jawa Barat TA 2017, pendapatan sebesar Rp 30,5 Triliun, sementara PAD yang masuk Rp 16,5 Triliun, sehingga sisa pendapatannya berasal dari pajak atau sekitar Rp 13,9 Triliun dalam bentuk Dana Perimbangan. Peran pajak ini sangat penting, sangat dominan, dan jika digabung dengan kabupaten/kota (di Jabar), itu (pendapatan) jauh lebih dominan. Terus pendapatan gabungan 2017 (kabupaten/kota) Rp 108 Triliun, PAD Rp 35 Triliun lebih, Dana Perimbangannya Rp 60 Triliun lebih. Dengan kata lain, diharapkan masyarakat juga mengawasi belanjanya, kalau pengawasan dari 


\section{Kebijakan: Jurnal Ilmu Administrasi \\ Volume 12, Nomor 1, Januari 2021 \\ E-ISSN: 2656-2820 \\ P-ISSN 1829-5762}

pendapatannya. Nah, belanjanya buat apa. Misalnya, di kabupaten/kota lebih banyak untuk gaji pegawai, nah itu ada masalah. Harusnya kan semaksimal mungkin untuk pembangunan daerah tersebut. Kepala Kanwil DJP Jabar I menambahkan, bagi WP yang tidak membayar pajak akan dikenakan sanksi. Sanksi bisa berupa pemanggilan untuk pemeriksaan, hingga penyidikan apabila ada indikasi pidana. Tinggal kesadaran warga negara ditingkatkan, bahwa mereka (WP) wajib membayar pajak, dan pajak tersebut ternyata menjadi bagian penting untuk pembangunan bangsa. Karena itu, atas nama Pemerintah Provinsi Jawa Barat mengajak, menghimbau kepada seluruh Wajib Pajak di Jawa Barat, baik itu perorangan maupun badan untuk bayar pajak. Karena pembangunan Jabar ini dilakukan salah satunya dengan menggunakan anggaran dari pajak yang dibayar oleh warga Negara. Dengan demikian, bayar pajak sama dengan mengamankan negara ini, sama dengan membangun negara ini, sama dengan menjamin negara ini untuk generasi masa depan, dan itulah manfaat pajak. Untuk pelaporan SPT Pajak perorangan paling lambat dilakukan pada 31 Maret 2018 sementara untuk badan pada 31 April 2018.

Hasil wawancara dengan kepala Kantor Wilayah Direktorat Jenderal Pajak Jawa Barat II, menyatakan bahwa kepatuhan Wajib Pajak di wilayah kerja Kantor Wilayah Direktorat Jenderal Pajak Jawa Barat II dalam melaporkan Surat Pemberitahuan Tahunan 2016 tercatat sebanyak 52 persen. Angka tersebut meliputi wajib pajak yang merupakan perorangan dan perusahaan. persentase tersebut setara dengan 1,2 juta Wajib Pajak, dihitung dari 2,4 juta Wajib Pajak pemilik Nomor Pokok Wajib Pajak. Namun yang memiliki kewajiban melaporkan SPT hanya 1,9 juta. Hanya saja, Wajib Pajak yang membayar pajaknya dengan patuh jauh lebih rendah dari jumlah Wajib Pajak yang sudah melaporkan SPT, yang membayar pajak hanya 4.581 Wajib Pajak, Rendahnya kesadaran Wajib Pajak membayar pajak ini diduga dilatarbelakangi alasan beragam. Bisa saja kelalaian, atau bahkan kesengajaan, dan tidak dipungkiri juga mungkin masih ada yang kurang mendapatkan pemahaman. Karena itu, Kanwil DJP Jabar II akan tetap giat menyosialisasikan edukasi seputar pajak yang diharapkan bisa mendongkrak kesadaran Wajib Pajak membayar pajak juga melapor SPT.

Hasil wawancara dengan Kepala DJP Kanwil Jabar III, menunjukkan Kepala Kantor Wilayah Direktorat Jenderal Pajak (Kanwil DJP) Jawa Barat III, merasa bangga dengan capaian SPT Tahun ini. Sebanyak 38 persen Wajib Pajak (WP) di wilayahnya telah melaporkan surat pemberitahuan (SPT) pajak mereka. Tahun 2017 ada peningkatan. Target tahun 2017 terdapat 30 persen yang melaporkan SPT, ternyata per-tanggal 28 Maret 2018 tercatat 38 persen. Presentasi tahun 2017 hasilnya lebih bagus dari tahun 2016. Hal ini dilihat baik dari prestasi secara nasional maupun hitungan pribadi dibandingkan tahun kemarin. Target WP yang membayarkan pajak tahunannya pun dibuat meningkat. Jika tahun kemarin Kanwil DJP Jawa Barat III mentargetkan sebanyak Rp 15 triliun, maka untuk tahun 2018 ini dinaikkan menjadi Rp 18 triliun. Kenaikan presentasi WP yang melaporkan SPT-nya ini menurut KaKanwil DJIP Jabar I, dikarenakan tingkat kepatuhan WP yang ikut meningkat. Salah satu pemicunya, karena adanya tax amnesty kemarin yang diikuti oleh kalangan pejabat. Kepatuhan WP kian meningkat, karena tahun kemarin ada tax amnesty, jadi bisa mendorong WP sadar akan membayar pajaknya. Karena kemarin baik Presiden ataupun Menteri banyak yang ikut tax amnesty.

Kakanwil DJP Jabar III juga menyatakan dengan meningkatnya jumlah pajak yang diterima, hal ini akan meningkatkan jumlah APBN. Kedepannya APBN bisa digunakan untuk membangun bangsa ini. Di Kanwil DJP Jabar III sendiri tercatat WP sebanyak 1.139.224. Dengan perbandingan untuk badan atau instansi sekitar 61 ribu dan pribadi sebanyak 1.078.000. Jumlah SPT yang diterima per- tanggal 28 Maret sendiri untuk badan atau instansi sebanyak 6,5 persen. Untuk karyawan sebanyak 40,8 persen dan nonkaryawan 25,3 persen. Sementara itu untuk e-filling badan sebanyak 3.011 WP dan pribadi 243.960 WP. Batas pelaporan SPT bagi pribadi disebut Isnaeni berakhir besok (31/3). Sementara bagi WP badan berakhir 
akhir 30 April 2018. Bagi WP yang masih membutuhkan bantuan untuk mengisi $e$ - filling maupun meminta EFIN, tiap KPP disebut akan terus melayani hingga Sabtu dengan jam buka pukul 08.00 WIB hingga 17.00 WIB. "Weekend atau Sabtu KPP kita buka. Kita layani WP sampai Sabtu. Mangkanya bagi WP jangan ragu untuk datang jika memang membutuhkan bantuan. Terakhir, dirinya menyebut bahwa pendapatan pajak terbesar sebenarnya berasal dari WP badan. Untuk periode Januari sendiri 2018, Kanwil DJP Jabar III mengalami peningkatan dengan penerimaan SPT 40 persen, naik dibandingkan periode Januari tahun 2017.

Hasil wawancara lainnya, kepala Kantor Direktorat Jenderal Pajak (DJP) Wilayah Jabar II meminta data-data perusahaan di wilayah Bekasi - Karawang kepada Pemprov Jabar. Data itu akan dimanfaatkan untuk mengejar wajib pajak yang masih belum memenuhi kewajiban pajaknya. DJP Wilayah Jabar II saat ini tengah berupaya menggenjot pemasukan pajak dari sektor industri karena sejauh ini masih ada potensi pajak yang belum tergali. Kepala DJP Jabar II Adjat Jatnika meminta bantuan Pemprov Jabar terkait data perusahaan. Kalau tidak dibantu Pemda, susah meningkatkan pendapatan pajak. Data perusahaan tersebut sangat penting karena bisa saja ada yang belum terdata sehingga tidak terpungut pajaknya. DJP Jabar II meminta data perusahaan yang berada di wilayah Bekasi dan Karawang. Dengan kata lain, DJP punya data jika datang ke perusahaan, data dari Pemda segini kenapa bayar pajaknya kecil. Lebih lanjut Kakanwil DJP menyebut, perlu menggali potensi pajak dari industri dan perusahaan di dua kawasan tersebut. Sebab tingkat kepatuhan dilihat dari Surat Pajak Tahunan (SPT) baru 50 persen. Pada 2016 lalu pendapatan pajak yang didapat mencapai Rp 25 triliun. Untuk tahun 2018 kita menargetkan pendapatan pajak sebesar 34 triliun rupiah. Sekda Jabar siap membantu DJP Jabar Wilayah II untuk menggali potensi pajak yang selama ini belum didapat. Kita akan siapkan data yang dibutuhkan Ditjen Pajak. Sekda menambahkan, pemberian data kepada DJP sebetulnya sudah sering dilakukan. Karena Pemprov berkepentingan untuk mendapat dana bagi hasil pajak baik dari pajak penghasilan atau pajak pertambahan nilai yang didapat. Dengan kata lain, tidak semua wajib pajak yang terdaftar telah mengisi formulir Surat Pemberitahuan Pajak (SPT), yaitu: hanya 56,72\%, tidak semua wajib pajak yang terdaftar telah mengisi formulir Surat Pemberitahuan Pajak (SPT), yaitu hanya 62,12\%; tidak semua wajib pajak telah mengisi Surat Pemberitahuan Pajak (SPT) dengan benar, yaitu hanya 72,23\%; tidak semua wajib pajak telah menyampaikan Surat Pemberitahuan Pajak (SPT) tepat pada waktunya, yaitu hanya 69,72\%; tidak semua wajib pajak tidak melaporkan semua objek pajaknya dengan benar, yaitu hanya $78,28 \%$; tidak semua wajib pajak telah menerapkan tarif pajak secara tepat dalam menghitung pajak yang terutang, yaitu hanya $82,12 \%$; tidak semua wajib pajak telah menghitung pajak yang terutang secara benar, yaitu 92,17\%; semua wajib pajak tidak menyetorkan sendiri pajak yang terutang, yaitu hanya $62,17 \%$; tidak semua wajib pajak menyetorkan pajak yang terutang tepat pada waktunya, yaitu hanya $71,51 \%$.

\section{SIMPULAN}

Strategi Penerapan Sistem Informasi E-filing pada Direktorat Jenderal Pajak Kantor Wilayah Jawa Barat I, II, dan III telah berjalan cukup baik dan mendukung hasil penelitian sebelumnya. Namun demikian strategi penerapan sistem informasi $e$-filing belum optimal. Hal ini cukup beralasan, ditemukannya fakta bahwa strategi penerapan system informasi $e$-filing belum mencapai ke seluruh sasaran, yaitu: seluruh wajib pajak aktif, karena kurang sosialisasi ke Wajib Pajak dan kesadaran dari Wajib Pajak sendiri. Meskipun demikian, strategi penerapan system infromasi e-filling mendapatkan respon yang positif dari Wajib Pajak. Temuan lainnya, bahwa strategi penerapan sistem informasi e-filling selama tahun banyak mengalami kendala dan hambatan baik dari wajib pajak itu sendiri maupun dari Kantor Pelayanan Pajak (fiscus). Terdapat tiga hambatan utama yang teridentifikasi, yaitu: (1) sosialisasi yang kurang merata ke wajib pajak, 
(2) wajib pajak tidak dapat menggunakan internet dan, (3) antrian yang masih panjang dalam mendapatkan e-fin.

Kondisi Kepatuhan Wajib pajak dalam memenuhi kewajibannya dinilai rendah, hal ini terbukti hanya 52 persen wajib pajak yang telah melaporkan SPTnya, dan mengalami penurunan yang cukup bermakna dibandingkan tahun sebelumnya. Penurunan ini cukup beralasan, mengingat jumlah WP yang memiliki NPWP meningkat, namun tidak melaporkan SPTnya. Argumentasinya bahwa Wajib Pajak yang mendaftar sebagai wajib pajak, meskipun memiliki NPWP, namun tidak berpenghasilan (karena memiliki NPWP sekedar memenuhi syarat melamar pekerjaan dan/atau mendapatkan kredit dari Bank).

Kendala-Kendala yang dihadapi Kantor Pelayanan Pajak di Lingkungan DJP Jawa Barat, meliputi: Kendala dalam Implementasi Kebijakan, yaitu: (1) Kekuasaan, kepentingan dan strategi dari aktor yang terlibat, (2) Karakteristik lembaga dan rezim yang berkuasa, serta (3) Tingkat kepatuhan dan adanya respon dari pelaksana. Kendala dalam Aspek e-Governance, yaitu: (1) Partisipasi, (2) Sumber Daya Manusia, (3) Infrastruktur, dan (4) Dukungan dari pemerintahan. Kendala dalam Penerapan Sistem Informasi e-Filing, yaitu: (1) Dalam hal mengajukan permohonan $e$-FIN, terdapat kewajiban wajib pajak yang harus dilalui, (2) Setelah memiliki $e$-fin, wajib pajak harus mendaftarkan diri agar memiliki akun wajib pajak di djponline, dan (3) Setelah memiliki akun, wajib pajak akan bisa menyampaikan SPT melalui $e$ filling.

Strategi penerapan system informasi $e$-filing berperan dalam mengoptimalisasikan kepatuhan wajib pajak, disatu sisi kepatuhan wajib pajak menurun, namun bukan akibat dari strategi penerapan sistem informasi $e$-filing yang tidak berhasil, tetapi lebih kepada argument, bahwa: (1) Terdapat Wajib Pajak yang membuat NPWP yang tidak dilaporkan SPTnya; (2) SPT yang disampaikan melalui $e$-filing masih dinilai rendah oleh Fiskus. Hasil penelitian ini mendukung dan masih relevan dengan hasil penelitian sebelumnya, sehingga dapat dijadikan altenatif bagi pembuat kebijkan dalam mengoptimalisasikan kepatuhan wajib pajak dengan mempelajari strategi penerapan system informasi e-filing secara baik dan benar.

\section{DAFTAR PUSTAKA}

Abdul, Ambali Raufu. 2009. E-Government Policy : Ground Issues in E-Filling System. European Journal of Social Sciences. Volume 11, Number 2.

Alabede, James O. Zaimah. 2011. Tax Service Quality and Compliance Behaviour in Nigeria: Do Taxpayer's Financial Condition and Risk Preference Play Any Moderating Role? European Journal of Economics, Finance and Administrative Sciences. ISSN 1450-2275. Issue 35

Alink, Matthijs and Victor Van Kommer, 2009. The Dutch Approach: Description of the Dutch Tax Administration, Second Revised Edition, IBFD.

Alink, Mathijs, and Victor Van Kammer. 2011. Tax Administration. Amsterdam-Netherland: IBFD.

Auerbach, Alan J. and Kent Smetters. 2017. The Economics of Tax Policy. Inggris: Oxford Univesity Press

Atawodi, Ojochogwu, Winnie Ojeka, and Aanu Stephen. 2012. Factors That Affect Tax Compliance among Small and Medium Enterprises (SMEs) in North Central Nigeria, International Journal of Business and Management Vol. 7, No. 12; June 2012

Balachandran, V. and S. Thothadri. 2013. Taxation: Law and Practice. New Delhi: PHI Learning Private Limited.

Baltzan, Paige. 2012. Business Driven Information Systems. Third Edition. New York :McGraw Hill. International Edition.

Bateman, Thomas S., Scott A. Sbell., and Rob Konopasle. 2016. Management. $4^{\text {th }}$ Edition: New 
Kebijakan: Jurnal Ilmu Administrasi

Volume 12, Nomor 1, Januari 2021

E-ISSN: 2656-2820

P-ISSN 1829-5762

York: McGraw-Hill.

Belkaoui, Ahmed Riahi. 2011. Relationship Between Tax Compliance Internationally and Selected

Determinants of Tax Morale. http:/www.ssrn.com

Creswell, John W 2013(a). Qualitative Inquiry and Research Design: Choosing Among Five Approaches. $3^{\text {rd }}$ Edition. USA: Sage Publications.

Hadi Purnomo. 2009. Era Baru Kebijakan Fiskal (pemikiran, konsep dan implementasi) : Editor Anggito abimanyu \& Andie megantara. Jakarta: PT. Kompas Media Nusantara.

Mas'ud, Abdulsalam, Alhaji Aliyu and El-Maude Jibreel Gambo. 2014. Tax Rate and Tax Compliance in Africa. European Journal of Accounting Auditing and Finance Research. Vol. 2, No. 3, pp 22-30.

Masyhur, Hadi. 2013. Implementation System Administration Modern Tax Compliance and Taxpayers. Administration Business Journal. Vol. Vol. X, No. 3, November 2013, pp. 3217 -3228 .

., 2015. Tax Administration: Comparative Information on OECD and Other Advanced and Emerging Economies. Paris: OECD.

Olson, David L. 2015. Information Systems Project Management. New York: Business Expert Press. Pemerintah RI, 2007. PMK Nomor 54/PMK.09/2008 tanggal 17 April 2008 ini merupakan amanah dari Pasal 36C UU Nomor 6 tahun 1983 tentang Ketentuan Umum dan Tata cara Perpajkan sebagaimana telah beberapa kali diubah terakhir dengan UU Nomor 28 tahun 2007. ., 2010. Undang-Undang Nomor 28 Tahun 2009 tentang Pajak Daerah dan Retribusi Daerah. Jakarta: Menteri Hukum Dan Hak Asasi Manusia Republik Indonesia. ., 2011. Peraturan Direktur Jenderal Pajak Nomor : Per-39/PJ/2011. Tentang Tata Cara Peny ampai an Surat Pemberitahuan Tahunan Bagi Wajib Pajak Oran g Pribadi Y ang Menggunakan Formulir 1770s Atau 1770ss Secara E-Filing Melalui Website Direktorat Jenderal Pajak (www.pajak.go.id).

., 2015. Nota Keuangan dan Undang-undang Republik Indonesia Nomor 36 Tahun 2015 tentang Anggaran Pendapatan dan Belanja Negara Tahun Anggaran. Jakarta: Depkeu-RI. ., 2017. Undang-undang Nomor 18 Tahun 2016 tentang Anggaran Pendapatan dan Belanja Negara. Jakarta: www.kemenkeu.go.id/en/Data/nota-keuangan-apbn-2017. [diakses 28 Mei 2017]. ., 2006(a). Undang-Undang Nomor 22/1999 yang diperbaharui dengan UU No. 32 Tahun 2004 tentang Pemerintahan Daerah. ., 2006(b). Undang-Undang Nomor 25/1999 yang diperbaharui dengan UU No. 33 Tahun 2004 tentang Perimbangan Keuangan antara Pemerintah Pusat dan Pemerintah Daerah.

Rainer, R. Kelly and Cegielski Casey G. 2011. Introduction to Information Systems: Enabling and Transforming Business, 3 rd ed. USA: John Wiley \& Sons Inc. Rusdin., 2015. Metode Penelitian Soaial. Bandung: UnpadPress.

Robbins, Stephen and Timothy A. Judge. 2015. Organizational Behavior. 16 ${ }^{\text {th }}$ Edition. Global Edition. New York: Pearson Education-Always Learning.

Salehi, Mahdi 2008. Corporate Governance and Audit Independence: Empirical Evidences from Iran. International Journal of Business and Management, Vol. 3, No. 12, pp. 46-54 (AMICUS Indexed). 
Sawyer, Adrian J . and Andrew McLaren Cockburn Smith. 2016. Trends and Players in Tax Policy. https://www.researchgate.net/publication/ 303302487 TRENDS AND PLAYERS IN TAX POLICY New Zealand National Report [diakses 11/10/2017]

Sekaran, Uma dan Roger Bougie., 2016. Research Methods For Bussiness: A Skill Building Approach. $7^{\text {th }}$ Edition. New York: John Willey \& Sons Inc.

Serra, Pablo. 2005. Performance Measures in Tax Administration: Chile As A Case Study. Public Admin. Dev, 25, 115-124.

Shafir, Eldar. 2012. The Behavioral Foundations of Public Policy. New Jersey: Princeton University Press.

Simanjuntak, Timbul Hamonangan And Imam Mukhlis. 2012. Analysis of Tax Compliance and Impacts on Regional Budgeting and Public Welfare.International Journal of Administrative Science \& Organization, September 2012, Volume 19, Number 3, pp. 194-205.

Slemrod, Joel and Christian Gillitzer. 2013. Tax Systems. Cambridge-US: MITPress.

Solomon, Jill. 2007. Corporate Governance and Accountability. $2^{\text {nd }}$ Edition. England: John Wiley and Sons, Ltd.

Wheelen, Thomas L., J. David Hunger, Alan N. Hoffman, and Charles E. Bamford. 2018. Strategic Management and Business Policy: Globalization, Innovation, and Sustainability. 15 $5^{\text {th }}$ Edition. Global Edition. New York: Pearson Education.

Zain, Muhammad 2007. Manajemen Perpajakan. Edisi 3. Jakarta: Salemba Empat.

Zhu, An Fu Ren . 2007. Tax Management Theory and Management Strategy. Boston- Massachusetts: Northeast Finance University Press 